\title{
Maskulinitet, \\ sport og forbudte følelser
}

Af Ulla-Britt LilleaAs

Denne artikkelen er en presentasjon av idrettsmenns syn på kroppen, idrettspraksis og de roller og forventninger mennene møter og ma baindtere i forskjellige sammenbenger. Det rettes fokus mot vesentlige motsetninger i mennenes liv, samt de forventninger andre har til dem og som folger med de forskjellige posisjoner som mennene inntar på idrettsarenaen, på arbeidet og $i$ familien.

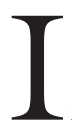

noen studier har man funnet at menn ikke har så lett for å vise følelser, og at de strever med en type (mannlig) selvbeherskelse som kommer til uttrykk som en splittelse mellom kropp og psyke (Seidler 1997, Ekenstam 1998). Det blir også hevdet at menn i mindre grad enn kvinner snakker om sine lidelser, mange benkter at noe er i veien og lider heller i stillhet (Helgeson 1995, Sjørup Simonsen 2003). Forfatterne knytter denne formen for selvbeherskelse til maskulinitet, og mye tyder på at dette er et svært kompleks felt som krever mer forskning. En viktig spørsmål er hvordan menn opplever egne emosjoner, og hvilke muligheter og behov har de for å vise følelser? Hvilke forventninger møter menn og hvilke forventninger har de til seg selv? Disse og flere spørsmål har blitt tematisert i et prosjekt om menns kroppsvaner $^{1}$ og helseforståelse. ${ }^{2}$ Et av siktemålene med prosjektet har vært å få mer kunnskap om menns subjektive opplevelser og erfaringer med det som skjer i og med 
kroppen. Utvalget består av en gruppe idrettsmenn og en gruppe menn som har hatt hjerteinfarkt, og i denne artikkelen er det idrettsmennenes arbeidsvaner, innstillinger og følelser som skal belyses. Ved en nærmere utforskning av slike temaer kan vi få dypere innsikt i hvorfor mange menn benekter sine problemer.

\section{KROPPSLIG BEREDSKAP SOM VANE}

Prosjektet om menn er en videreføring av min tidligere forskning, hvor jeg ofte har blitt slått av at kvinner og menn framstiller kroppen som en maskin (Lilleaas 2003, Lilleaas og Widerberg 2001). I disse fortellingene er kroppen tatt for gitt, den oppfattes som gjenstand som kan brukes til den går i stykker. Kvinnene snakket mye om at selv om de var slitne, klarte de ikke å hente seg inn eller hvile (Lilleaas 2003). For kvinnene var følelsen av å alltid være i kroppslig beredskap for andre - spesielt familien - den mest fremtredende. Denne tilstanden kan forståes som en form for plikt- og ansvarsfølelse som er innskrevet i kroppen. Denne plikt- og ansvarsfølelsen mener jeg kan tilskrives en del av en kvinnelig habitus i Bourdieusk forstand (Bourdieu og Wacquant 1993), og være et bidrag til å kaste lys over en vanemessig tenkning som tilegnes gjennom en type kjønnet praksis. Et eksempel på denne praksisen er at kvinner får eller tar ansvaret for store deler av familiearbeidet. Hos mennene fant jeg ikke den samme beredskapen overfor familien, men derimot en sterk pliktfølelse overfor jobben. Trøtthet og helseplager var et mindre problem selv om de arbeidet i en bedrift i kontinuerlig omstilling, og hadde levd med oppsigelsestrusselen i mange år. Mennene kunne ikke være trøtte når de kom hjem for da ble det synlig at jobben tok alt, og da krevde familien at de skulle jobbe mindre (Lilleaas og Widerberg 2001). Men når båndopptakeren var slått av, kom det fram at mennene hadde fått en rekke signaler om at kroppen var overbelastet. Mange led av alvorlige plager som høyt blodtrykk, hukommelsessvikt og søvnproblemer som de aldri snakket med andre om. Det var disse funnene som inspirerte meg til å utforske menns kroppsvaner og helseforståelser.

\section{PROBLEMSTILLINGER OG MATERIALE}

Det er en idrettsklubb som er nedslagsfeltet for denne studien, og materialet består av kvalitative intervjuer med 15 mannlige håndballspillere.

Menn irettesettes og sosialiseres på ulike måter, lever forskjellige liv og gjør seg ulike erfaringer som vil være utslagsgivende for de arbeids- og kroppsvaner som etableres. Derfor har det vært viktig å få fram mennenes kroppsforståelse og levevaner sett i lys av rollen som idrettsutøver, ektemann og far. Toppidrettsutøvere lever av kroppen, samtidig som de utsetter den for ekstreme påkjenninger. I intervjuene har både gode og mindre gode kroppserfaringer vært et sentralt tema. I likhet med kvinners omsorgs- og arbeidsrolle, har menn en arbeids- og forsørgerrolle, og nå mer og mer en aktiv farsrolle som påvirker deres kroppserfaringer. Historisk sett har menn vært familieforsørgeren par exellence, og da kan deres pliktfølelse for jobben (her klubben) også forståes som en del av en mannlig habitus - dvs. som en innarbeidet kroppsvane. Et annet spørsmål har vært hva denne pliktfølelsen betyr for idrettsmennenes prioriteringer. Menn som ønsker å gjøre (idretts)karriere stilles overfor et valg mellom familie eller karriere, og da er det interessant å undersøke hvilke dilemmaer idrettsmennene opplever som de mest påtrengende ved å ha familie samtidig som de skal gjøre karriere innenfor toppidretten.

Selv om mannsrollen er i endring, er det fremdeles forventninger til at menn skal være sterke og i minst mulig grad vise svakhet (Seidler 1995). Følelser har vært et sentralt tema i intervjuene: Hvilke følelser opplever menn som legitime versus illegi- 
time? Hvor går grensen for emosjonelle uttrykk og hvilke regler er det som gjelder i idrettsfeltet? Med bakgrunn i disse spørsmålene vil jeg i denne artikkelen belyse idrettsmennenes forhold til maskulinitet, kroppserfaringer og følelser.

\section{IDRETTSMENNENE}

Håndballspillerne kan deles inn i to grupper, den ene gruppen er elitespillerne som er i alderen 25 til 35 år (de yngre). Den andre gruppen er old boys, og de er fra 35 til 65 år (de eldre). Old boysene har tidligere vært elitespillere, i dag trener de på eget lag. Av yrke er halvparten lærere, noen er ingeniører eller selvstendig næringsdrivende, mens andre er i typiske kvinneyrker som sykepleier eller førskolelærer. Med unntak av de tre yngste har alle egen familie. Arne er en typisk representant for de yngre elitespillerne med familie:

Han er 29 år, tidligere var han kroppsarbeider, men for et par år siden tok han høyskoleutdanning. Nå har han en jobb hvor han trives godt, men den er krevende, og hver dag blir han utfordret til å bruke mange sider ved seg selv. Han har vært sykmeldt i lengre tid på grunn av en skade, men har begynt å trene litt igjen. Han har to barn - og kona har en kronisk sykdom. Men det er vanskelig å gi seg med håndballen, kona jobber deltid, og familien har blitt vant til den ekstrainntekten spillingen gir. Han legger ikke skjul på at treningen og samværet med de andre gutta representerer en viktig del av livet, og at idretten gir ham mye $\mathrm{i}$ den forstand at han får drive med det han interesserer seg aller mest for her i livet - spille håndball. Han beskriver seg selv som en tidligere egoist, men etter å ha fått barn har han blitt mykere $\mathrm{i}$ kantene. Men fremdeles er han den tøffeste spilleren på banen, der er han gjerne røff og hissig mot andre spillere. Det gir ham status i klubben, men det medfører også at han ofte føler seg splittet som menneske. Flere ganger under intervjuet sier han at han fø- ler seg som en person når han er på banen eller sammen med gutta, og en annen når han er hjemme.

Det Arne forteller er typisk for hvordan mange av de yngre spillerne med familie opplever situasjonen. De er slitne, noen har vært med på laget i mange år og har ikke den samme innsatsviljen som før. De trener to ganger om dagen, en times økt før de drar på jobb, to timer om kvelden, og i helgene spiller de kamper. Det betyr at mennene tilbringer det meste av tiden borte fra familien, og for å klare å holde det tette treningsprogrammet har alle redusert arbeidstid. Håndballen er en svært viktig del av disse mennenes liv, og det er ikke i jobben, men på idrettsarenaen de gjør karriere. Men - de fremhever også at de er moderne menn som er opptatt av både likestilling, og det å være tilstedeværende fedre.

\section{EN SLANK OG VELTRENET KROPP}

Idrettsmennene beskriver herrehåndball som en kampsport. For å bli en god spiller må man ha den rette innstillingen og den 'riktige' kroppen. I elitedivisjonen må man vise at man både er en fighter, er utholdende og i svært god fysisk form. Bjørn (37) er trener, og forklarer at spillere som tar sikte på å nå toppen er nødt til å ha et instinkt for konkurranse. Selv foretrekker han å ha tøffe, sterke og gjerne litt hensynsløse spillere på laget.

Noen av spillerne opplever treningskravene som vanskelige å oppfylle, mens andre mener det viktigste er å lære seg å håndtere kravene og innse at konkurranse er en del av spillet. Noen er kritiske til den harde treningen, særlig fordi de i perioder hvor de har belastningsskader, føler seg presset til å spille lenge før skaden er leget. Men stort sett tar mennene det for gitt at kroppen skal presses, helst mer enn den tåler. Selv om presset på den enkelte om å være en 'vinner' kan oppleves som en belastning, ser de fleste mange fordeler ved å få utfolde 
seg i et idrettsmiljø. I dag er hele samfunnet innrettet mot det de kaller en konkurransementalitet, og mange mener at uansett hva man er eller hvor man arbeider, må man prestere for å lykkes.

Kroppsidealet i klubben er den raske, faste, slanke og smarte kroppen, og som det går fram av sitatene nedenfor, har spillerne helt bestemte meninger om hvordan en kropp bør være. Det gjelder både størrelse, styrke og utseende:

"Jeg vil se godt ut og holde vekten." "Jeg liker ikke slappe og feite kropper, menn med slappe mager er helt forferdelig."

"Kroppen skal være slank og veltrenet, det synes i hvertfall jeg."

"Jeg vil helst ha en kropp som jeg føler at jeg har under kontroll."

"Jeg vil ha en kropp som gjør som jeg vil uten å bli trøtt.”

Målet for håndballspillerne er å ha en kropp som er presentabel, det er ikke nødvendig med så store muskler, og den bør ikke se stor og 'bolete' ut. En senesterk kropp vil være helt perfekt. Noen peker på at det å ha en kropp som er velbygget gir dem både en konkurransefordel og en følelse av å være i balanse. De fleste er overbevist om at uten den daglige treningen vil kroppen forfalle, og det verste som kan skje er at kroppen blir "utflytende og kvapsete". Øker vekten, tas det som et tegn på at de har mistet kontrollen. På spørsmål om de pleier å slanke seg, svare mennene at slanking er en kvinnegreie, de trener bare enda mer. Og det er interessant når de sier at slanking er et ord de aldri bruker når de prøver å gå ned i vekt. De yngre sier de er ganske fornøyd med den kroppen de har, en og annen muskel kunne nok vært litt større, men de fleste elitespillerne opplever seg selv som attraktive i nærmiljøet. Ofte fremheves håndballgutta som lokalmiljøets helter, når de har spilt kamper slås det stort opp i lokalavisen.

Bildet som håndballspillerne tegner av den ideelle idrettskroppen kan tolkes som et uttrykk for hvilke praksiser som gjelder i idrettsfeltet. De uskrevne og uuttalte reglene for hva som er legitimt for mannskroppen gjelder her i stor grad kroppens representativitet og tilgjengelighet (Bourdieu 1992, 129). Det som skjer kan sammenliknes med det Bourdieu betrakter som en kulturell innprenting som skaper skjemaer for en viss type atferd, Han advarer imidlertid mot å redusere denne innprentingen til normer som bare påtvinges mennesker, dette er regler som håndballspillerne også gir seg selv, og som internaliseres i form av vaner. Vanetenkningen får blant annet konsekvenser for spillernes forhold til risiko, skader og en mer og mer aggressiv spillestil.

\section{IDRETTENS GEVINSTER OG OMKOSTNINGER}

\section{Kroppens sårbarbet}

Mennene vil helst snakke om håndballens positive sider, men mange er også klar over idrettens negative sider. På dette laget er skadene omfattende, og mest utbredt er brukken nese, fingre, håndledd og skulder. Thomas (39) har vært mye skadet, men synes likevel han har vært heldig:

"Jeg har hatt mange bruddskader, men det har stort sett bare vært ... jeg vet ikke hvor mange brudd jeg har hatt på fingrene, men en seks syv brudd må det være. Så er jeg operert i handa, og nesa har jeg knekt et par ganger. Sånne ting, men det har aldri vært noe alvorlig. Ja, akillessenen da, og kneet, det er jo litt verre, men jeg skyver det vekk og prøver å ikke tenke på det.”

Få tror det er sunt å drive idrett på elitenivå, det Frank (49) sier illustrerer det mange tenker:

"Idrett er nå engang å ta sjanser og sette kropp og helse på spill. Jeg var jo klar over farene, at jeg ville få bivirkninger i for ek- 


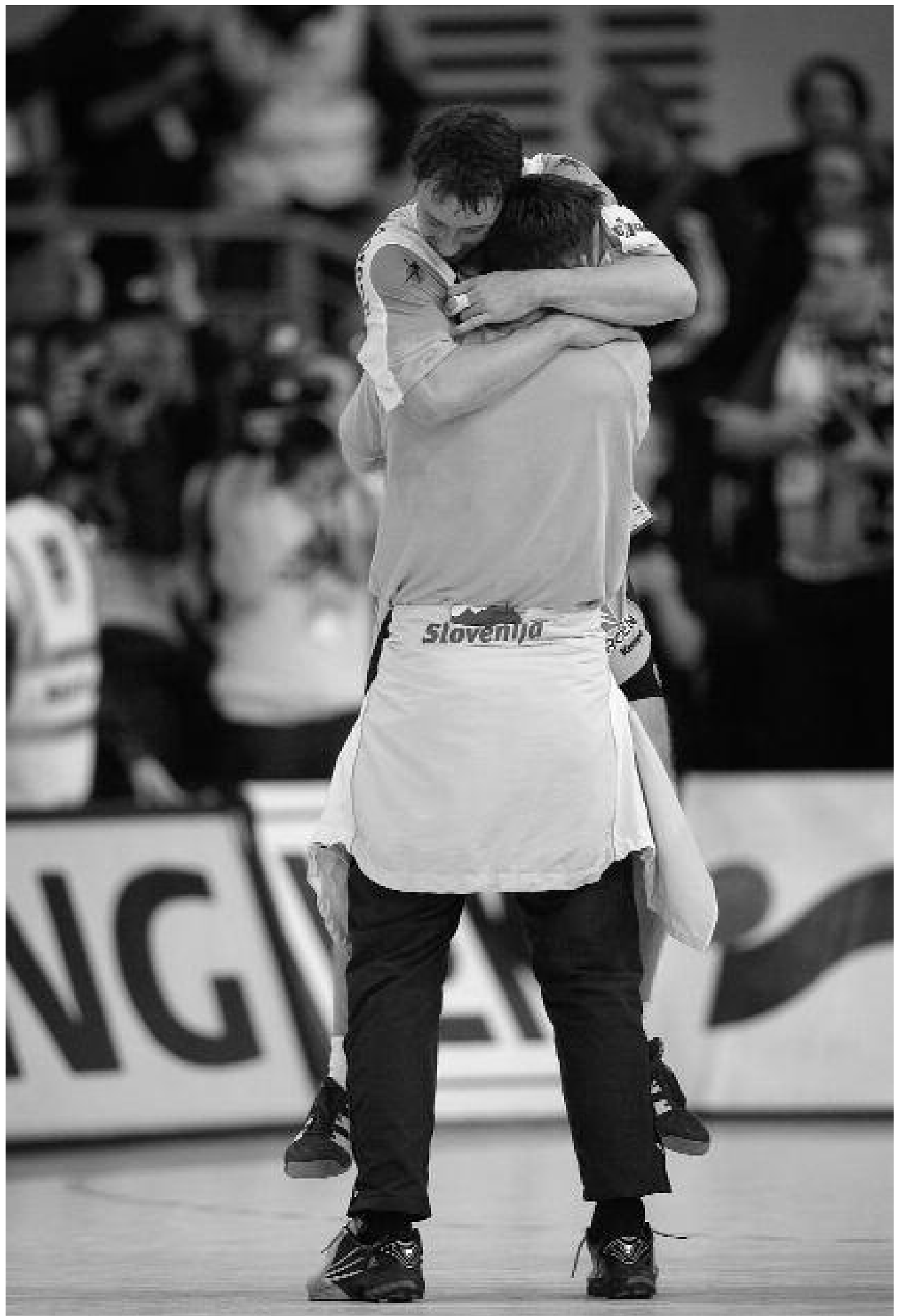

Polfoto, fotograf: Peter Hove Olesen 
sempel knærne. Når du ramler ti ganger hver kveld uten knebeskyttere så kan du jo tenke deg selv.”

Mennene vet at brudd, skader og smerter er noe av den prisen de betaler for å være på toppen, det er bare sånn det er, og ikke sjelden legitimeres risikoatferd og alvorlige skader i media av både trenere og respekterte idrettsmenn. I følge lagets trener er det hans oppgave å sørge for at spillerne utvikler en mer aggressiv spillestil. Å være på elitelaget er, som en av spillerne sier, ingen frøkensport, det gjelder å angripe og være røff mot de andre spillerne. I kamp skal spillerne være så kroppsnære som mulig, og gjerne gå inn med enda grovere taklinger enn før. Her er det snakk om en hårfin balanse mellom det som betraktes som fysisk røff behandling, og vold. Flere forteller at de har vært utsatt for det som utenfor idrettsarenaen ville blitt definert som vold:

“Jeg ble jo kicka ned i ansiktet så jeg brakk nesa. Det var en motspiller, og så spilte jeg med ansiktsmaske, og da var det noen som gikk direkte på å slå meg i ansiktet. Det var usportslig, og ikke vanlig, men spiller du håndball så må du rege med å få noen trøkker her og der, Det er bare sånn det er.”

Man lærer seg å bli mer aggresiv og bruke kroppen slik at man kan sette andres kropper ut av spill. Flere har selv benyttet seg av ufine metoder på trening og kamper, og på den måten kan herrehåndball beskrives som en trening i en viss type mannlighet.

\section{Trivialisering av kvinner}

Senere års forskning om sport og kjønnsprosesser har pekt på at sport er en institusjon der flere typer av maskulinitet blir konstruert og rekonstruert (Connell 1983, Messner 1990, Young 1993). Innenfor typiske mannsidretter har det vært vanlig å være tolerant overfor aggressiv atferd, og som en del av et større maskulinitetspro- sjekt, har det skjedd en idealisering av det å være risikoorientert. Den amerikanske mannsforskeren Messner mener at innenfor de mest populære idrettene, blir kroppen rutinemessig omdannet til et våpen brukt mot andres kropper. Resultatet er ofte smerter, alvorlige skader og til og med død (Messner 1990, 203). Andre beskriver at toleranse for risiko og skader ofte fremheves og legitimeres for å imponere andre (White, Young \& Mcteer 1995). Sportsgrener som kunstløp og turn verdsettes lavere enn f.eks. fotball og ishockey, hvor fysisk vold er framtredende. En grunn til å degradere noen idretter kan være at der hvor den fysiske volden er fraværende er mindre potensiale for å reprodusere hegemonisk maskulinitet eller ideen om den 'naturlige' kjønnsforskjellen (White, Young og McTeer 1995). Idretter som legger opp til fysisk konfrontasjon, befestes som et maskulint territorium, i hovedsak gjennom en ekskludering eller trivialisering av kvinner (Lenskyj 1986 i White, Young og McTeer 1995). Hvorvidt kvinner er fysisk sterke nok til å delta i sportsgrener med fysisk konfrontasjon, inngår i denne diskursen.

Mennene i min studie - enten de er elitespillere eller old boys - er skjønt enige om at selv om kvinnelandslaget $\mathrm{i}$ håndball regnes for å være best i Norge, er dette bare et medieskapt fenomen. Tronds (51) uttalelse er et eksempel på mennenes innstilling til kvinnehåndball:

"Media fokuserer der det er stjerner og penger, ingen spør hva som er vanskeligst, å være på herresiden eller damesiden. Det er er en prestasjon det jentene har gjort, men det er et hav av forskjell mellom de to idrettene."

Det understrekes sterkt i intervjuene at herrehåndballen både er tøffere og råere, og at det er opplagt at det kreves langt mer av mannlige enn av kvinnelige håndballspillere. 


\section{Liten tid til familien}

Selv om skadene tas for gitt av mange spillere, er det flere som opplever den høye skadefrekvensen som en negativ side ved eliteidretten. En annen negativ side som småbarnsfedrene trekker fram, er at de aldri får tid til å være så mye sammen med barna som de gjerne ville. Flere er plaget av dårlig samvittighet, men de pleier å ta kona med på råd, og sålenge hun ikke setter ned foten fortsetter de som før. Det er mange som deltar i familiearbeidet så ofte de kan, men som en sier: "Det er jo kona som er mest hjemme så det blir til at hun styrer mest." Idretten setter klare grenser for denne spillerens deltakelse hjemme, og han legger til: "Det ville aldri fungert hvis ikke kona var så forståelsesfull når det gjaldt min håndballinteresse."

Mennene synes de er for lite hjemme, men mange trøster seg med at familiene deres er så godt sammensveiset. Konene deres møtes når de spiller kamper, og det tror de betyr mye for at konene godkjenner mennenes fravær. Men i intervjuene går det fram at ikke alle er like fornøyd, noen av konene har begynt å si i fra og da har man kanskje nådd en grense, sier en av dem som vil vurdere å legge opp til neste år. På spørsmål om hva mennene ville gjort hvis de kunne velge om igjen, svarer flertallet at de ville gjort akkurat det samme. Ingen angrer på at de ble elitespillere, både spenningen ved å konkurrere, kampene, reisene og ikke minst det gode kameratskapet, oppveier for de negative sidene ved håndballen.

\section{DeT MASKULINE OG FEMININE}

\section{Kontrollerte og risikoorienterte}

Jeg har også spurt mennene om hvordan de ser på seg selv som type og som mann, og da er det mange som fremhever hvor målrettet de er. Noen omtaler seg selv som en krutttønne med et sinnsykt temperament eller med et utpreget kampinstinkt.
Andre legger størst vekt på at de er trygge på seg selv, og at denne tryggheten gjør at de framstår som menn med høy selvtillitt. På spørsmål om hvordan de tror at omgivelsene opplever dem, er svarene litt annerledes. De fleste tror at andre synes de er veldig tålmodige, blide og utadvendte - og stort sett i godt humør.

Når mennene skal beskrive seg selv er det mange som gir inntrykk av at de stort sett har alt under kontroll - spesielt de eldre gjør det - men lenger ut i intervjuet kommer både bekymringer, kriser og helseplager fram. Frank har hatt to tilfelleller av blodpropp, men var heldig og ble reddet $\mathrm{i}$ siste øyeblikk. Nå går han på blodfortynnende medisiner som betyr at en skade eller et slag mot kroppen vil være livstruende for ham. Han burde gitt seg for lenge siden med både trening og kamper, og på spørsmål om hvorfor han ikke gir seg, sier han at selv om han snart er 50 år, er det fremdeles en viktig del av livet hans å ta sjanser. Å ta risiki kan være en måte å håndtere sykdommen på, da kan han bevise for seg selv at han fremdeles har kontroll og slipper å redefinere identiteten sin. For en tidligere elitespiller kan det å bli tvunget til å trappe ned aktiviteten og bli mer passiv, reise noen identitetsdilemmaer og skape usikkerhet om den posisjonen man har i et idrettshieriarki. En måte å håndtere alvorlig sykdom på, kan være å benekte alvoret ved å gå tilbake til sine sportsaktiviteter så fort som mulig. Det var et av hovedfunnene i en studie av menn med kreft, benektingen var et utslag av at mennene nektet å bli konfrontert med sine følelser (Gordon 1995, 258). Det kan også være et utslag av at man søker bekreftelse på at kroppen fungerer igjen.

For å kunne delta i konkurransen i idrettsfeltet blir elitespillerne tvunget til å sette helsa på spill, og risikoorienteringen som preger dem lar seg ikke uten videre bryte selv om de slutter som elitespiller og går over til old boys. For noen av old boysene kan det å ta sjanser også være en måte å 
håndtere tapet ved å måtte gi slipp på rollen som elitespiller og innordne seg i 'back stage'. Mange sier at den dagen man bestemmer seg for å slutte som elitespiller, er det det samme som å gå inn i en identitetskrise. Overgangen har vært større enn mange kunne forestille seg, og for noen oppleves dette som en trussel mot selvbildet. Alle vil at de yngre skal få slippe til, men statustapet kan oppleves som betydelig, og for de fleste har det tatt tid å venne seg til en mer tilbaketrukken rolle.

\section{Noen tviler på seg selv}

Til tross for at de fleste mennene i denne studien kan virke selvsikre og trygge på seg selv, er det mange som er usikre på hvordan en moderne mann bør være. Rollen som elitespiller har de mye kunnskap om, her har fedre, brødre, ledere og trenere vært forbilder. Men hvordan de skal være fedre og partnere, er særlig de yngre mer i tvil om. Knut (32) har tenkt endel rundt hvordan det er å være en moderne mann:

"Skal du gjøre det bra som mann i dag, må du lykkes både på jobb, hjemme og i fritiden. Jeg tror ikke faren min hadde det samme presset.”

De fleste tror det var mye lettere å være mann når fedrene deres var yngre:

"Dengangen var en mann en mann, og rollen var klar og definert. I dag er det mye snakk om hvordan en far skal være, og hva som karakteriserer den perfekte far.”

Likevel tror de at det er viktig det som skjer i dag, fordi menn blir mer bevisste på betydningen av likeverd og likestilling:

"Som mann må man akseptere at kvinnfolka vil ut og har sine egne behov, og jeg vil påstå at mannfolk har blitt flinkere til å bidra hjemme. Det ser jeg i vennekretsen også." (Petter 29 år)
Dagens unge menn må tenke mye mer over hvordan de oppfører seg overfor andre, og det synes mennene er positivt. Men noen opplever det som frusterende at de henger igjen i de gamle kjønnsrollene. Stein (42) reagerer på at det fremdeles er slik at menn alltid skal ta initiativet, mens kvinner oftere kan lene seg litt tilbake:

"Det forventes f.eks. at menn er kreative og overrasker kona med en liten reise, omtrent sånn å nei jøss, nå drar vi til Barcelona eller Roma en helg."

Dette er krav mennene møter hos andre, men det er også krav de har til seg selv. De føler at de må leve opp til både gamle og nye mannsroller, og mange av de yngre er opptatt av at de forventningene de møter på de ulike arenaene, ikke henger sammen. Hjemme skal de være både myke og harde på samme tid, og kravene $\mathrm{i}$ arbeidslivet og på idrettsbanen passer dårlig med de kravene som stilles til dem som moderne fedre.

\section{I pose og sekk}

Kravene til å være en tilstedeværende far og samtidig være med i sportseliten, opplever de fleste som uforenlig. Som elitespiller må man skrive under en kontrakt, og da sier en spiller ja til å gjøre det som klubben forventer. I følge treneren forekommer det at spillere med småbarn ikke dukker opp på trening på grunn av syke barn eller andre forhold i familien.

Målet for klubben er å holde seg i eliteserien. Dette er trenerne og klubbens tankegang, mens noen av spillerne ser annerledes på det. Knut (32) peker på at ingen kan forestille seg hvordan det er å være far før man selv får barn. Første gang han skulle bli pappa følte han at han ikke var klar for oppgaven. Målet var å gjøre håndballkarriere, men det ble ikke helt som forventet:

“Når man făr barn blir man en annen, da blir 
man plutselig en omsorgsperson, og den forståelsen hadde jeg ikke dengangen jeg sa ja til å være elitespiller. Å få familie gjør at du bare må prioritere."

Men mange klarer ikke å prioritere, mennene vil ha begge deler. Håndballen betyr inntekter og berømmelse, familien gir dem rikelig anledning til å være omsorgsperson samtidig som de făr omsorg og kjærlighet tilbake. Det går så lenge kona ikke klager, men gjør hun det, har det gjerne gått så langt at slitasjen i forholdet har blitt synlig.

\section{HÅNDTERING AV FORBUDTE FØLELSER}

\section{Fysisk aktivitet som en \\ inkorporert vane}

I en tidligere studie hvor jeg intervjuet småbarnsforeldre om deres syn på arbeidsdeling og kroppsvaner, går det fram at når det oppsto konflikter i parforholdet ville kvinnene snakke, mens mennene heller tok seg en løpetur for å riste av seg følelser som utålmodighet, irritasjon og sinne (Engelsrud og Lilleas 1999). For mennene var fysisk aktivitet blitt en kanal for følelser som de ikke fant utløp for ellers i hverdagen. Idrettsmennene bruker også fysisk aktivitet som en avreagering, og mange forteller at de ikke fungerer uten de daglige treningsdosene. Per (37) gir her en beskrivelse hva som skjer med og $\mathrm{i}$ ham når han ikke får utløp for temperamentet sitt:

"Jeg er en rolig type, men har et sinnsykt temperament som jeg fikk utløp for når jeg var elitespiller, men som jeg har større problemer med å kanalisere i dag. Derfor burde jeg trent mye mer enn det jeg gjør idag. Jeg blir urolig i kroppen, og får rett og slett vondt av det. Jeg blir også irritabel og innesluttet når det går for lang tid mellom treningen."

Den uroen som Per beskriver og som han opplever som svært kroppslig, kan også få en mer depressiv karakter. Når kona hans merker det ber hun ham om å ta seg en løpetur. Mennene kaller denne tilstanden for treningsnarkomani, og avhengigheten blir enda tydeligere i perioder hvor de ikke kan trene - som når de utsettes for skader av langvarig karakter - eller når de slutter som elitespiller og går over til oldboys. De som har det slik, føler seg nedstemte, rastløse og urolige.

Dette viser at fysisk aktivitet har blitt en nødvendighet for mange, eller som noen sier: "Jeg har alltid vært rastløs av natur." Det virker som treningen ikke bare handler om ferdigheter og utseende, for mange har den også blitt en innarbeidet kroppsvane. Det de fleste sier, er at de må ha sin daglige treningsdose for å føle seg vel. ${ }^{3}$ I kroppsbyggermiljø er treningsavhengighet et kjent fenomen, og kroppsbyggerne forklarer avhengigheten med at de får økt selvtillitt når kroppen er stor (Johansson 1998, 251). Ved å trene mindre, vil kroppen minske, noe som ville bety et dårligere selvbilde. Som jeg har vist tidligere, betyr kroppens utseende svært mye for håndballspillernes selvfølelse, men for mange er treningen også en måte å håndtere følelser de ikke ellers får utløp for. $\mathrm{Og}$ som jeg straks kommer tilbake til er det mye som tyder på at menns mer feminine sider må begrenses i miljøer hvor den hegemoniske maskuliniteten råder grunnen.

\section{Irettesettelsene}

Idrettsbanen er en av de få offentlige arenaene hvor det er tillatt for menn å vise fram et bredere følelsesreportoar - i hvert fall til en viss grad. Her kan spillerne være aggressive og glade, og til og med vise sorg og fortvilelse når det går dårlig for laget. På kamper kan menn gi uttrykk for sider ved seg selv som vanligvis må holdes i sjakk, de kan ta rundt hverandre, klemme og kysse, men et sted går det en grense. Kyssing på munnen er f.eks. ikke tillatt. For noen år siden tok Per (37) ut sin "enorme glede" 
under en målscoring, han tok ansiktet til en av de andre spillerne mellom hendene og kysset ham midt på munnen. Denne hendelsen ble skjellsettende for ham. Oppslagene $\mathrm{i}$ avisene var voldsomme, og familien ble oppringt av journalister som ville vite om han nå var blitt homse. Slike hendelser gjør inntrykk, og som han selv sier:

"Jeg er en fyr som tar ut mye på banen, også begeistring og glede. Det ble desverre totalt misforstått, og det har jeg jo merket meg."

Slike små og store irettesettelser lagres i kroppen, de huskes og disiplinerer menns følelser i en viss retning. Det betyr at visse emosjonelle uttrykk bør dempes for at det ikke skal settes spørsmålstegn ved mennenes mannlighet. Aggressivitet ikke bare tillates, spillerne både oppmuntres og trenes i å utvikle og ta ut slike følelser.

\section{Skjuler sine mykere sider}

Trening kan være én måte å håndtere vanskelige følelser på, en annen er å bruke ulike former for humor. Når håndballspillerne er sammen blir det mye fleiping og kødding, ${ }^{4}$ og det er lite rom for å snakke om alvorligere temaer. I følge mennene har de ingen tradisjon på å snakke om problemer, noe som blir svært tydelig når noen kommer i krise. En av oldboysene forteller at han gikk inn i en depresjon når kona forlot ham, alle rundt ham så at han hadde trøbbel, men ingen snakket om det. Selv lot han som om ingenting hadde hendt. En annen er langtidssykmeldt med diagnosen utbrent. I intervjuet er han svært åpen på sine problemer, men poengterer at han ikke ønsker å sette kameratene sine inn i situasjonen. Når vennegjengen er sammen har de det gøy, og snakker aldri om "sånne problematiske ting".

Det forekommer relativt sjelden at håndballspillerne snakker med andre menn om sine problemer, og mange har klare meninger om hvorfor menn ikke vil vise følelser.
Sitatene under er et utdrag av hva håndballspillerne sier om menns håndtering av følelser:

“Menn stenger av følelsene sine og forsøker å være tøffe og holde en maske utad."

"Menn er egentlig feige, det er derfor de ikke tør vise følelser."

"Mange menn forsøker å gjøre seg bedre enn de er, og det er noe av grunnen til at når de sprekker, så blir reaksjonen så voldsom."

“Mange menn viser følelser gjør det når de er alene."

"Når menn har tunge stunder vil de ikke bry andre."

Av sitatene går det fram at menn forsøker å skjule og kontrollere sine innerste følelser fordi de er feige, vil skjule sine mykere sider eller fordi de ikke vil bry andre. I følge håndballspillerne er det liten forskjell på kvinner og menns følelser, det er bare det at menn reagerer annerledes enn kvinner. Mange forteller om såre erfaringer fra oppveksten, og hvordan de lærte at gutter må skjule følelser som kunne tolkes som feminine. Gutter som gråt eller var lei seg, ble ofte satt på plass av omgivelsene. Bjørn (37) mistet faren sin da han var 15 år, noe han beskriver som en stor følelsesmessig krise. Han gråt, og viste sin fortvilelse åpenlyst blant venner og spillere på laget, da ble han raskt bedt om à skjerpe seg. Opplevelsen sitter i ham som en nederlagsfølelse, enda det er snart over tyve år siden. Bjørn sier han lærte noe om hvordan gutter skal takle vanskelig følelser, og det preger ham også i dag:

"Jeg var en fyr som viste følelser, men jeg opplevde noe som gjør at jeg alltid forsøker å skjule det jeg føler.”

Det betyr at det foregår en undertrykking av menns følelser som i stor grad utøves av menn. A sensurere følelser slik håndballspillerne her gjør, er i følge den amerikanske sosiologen Peter Freund (1990) lite 
helsebringende, og på sikt kan undertrykkingen føre til det han kaller følelsesmessig falsk bevisshet. Denne tilstanden oppstår når man har trent seg selv til å føle en ting, selv om man egentlig erfarer noe helt annet. Følelser har en sentral informasjonsoppgave i et hvert menneskes liv, og blokkering av disse informasjonsstrømmene kan få alvorlige konsekvenser for kroppen (Freund 1990, Damasio 1999).

\section{Seriøse kvinner og fleipete menn}

Selv om de fleste håndballspillerne vil ha det gøy når de er sammen, er det ikke alle som trives med denne omgangsformen. Per (37) skiller seg ut ved at han beskriver seg selv som en seriøs type, og ved å være kritisk til mannlige samværsrelasjoner:

\section{"Når menn er sammen går det mye i fleiping og det kan være ok noen ganger, men de fleste mennene jeg kjenner kan jeg ikke tenke meg å snakke med om følelser. Jeg er heller ikke av den typen som bare setter meg ned og legger ut om hvordan jeg har det. Det må være en situasjon hvor det egner seg å snakke om følelser pluss en person som jeg oppfatter som seriøs.” (Per 37 år)}

Men han er enig i det de fleste sier, at det er fint å snakke med kvinner for da kan man gå mer i dybden på problemene. Sammen med kvinner kan man både få hjelp til å løse kriser, og kanskje komme et skritt videre. Både de yngre elitespillerne og old boysene opplever at kvinner er mer seriøse, de åpner seg lettere og gir mer av seg selv i samtalen, sier de. Men legger til at et godt vennskap med en kvinne forutsetter fravær av sex. Noen kan snakke med kona om sine problemer, men slett ikke alle, ofte synes mennene at det er bedre å snakke med andre kvinner fordi de er mer objektive. Det er et ønske hos flere at de kunne snakke like godt med kona som med andre venner.

En viktig forskjell mellom de eldre og yngre, er at de yngre ser ut til å ha flere å henvende seg til når de har problemer. De har både kvinnelige venner, i noen tilfeller kona, og et par utvalgte kamerater de kan prate med. Noen få av de eldre har én god kamerat som de stoler på, og som de kan snakke med om alvorlige spørsmål. Men det er fortsatt slik at de fleste mennene i denne studien har problemer med å snakke om følelser når de er sammen med andre menn.

\section{Arlig kommunikasjon}

Men hva er det i samværet mellom menn som gjør det så vanskelig å være åpen og vise fram sine sårbare sider? Noen forskere hevder at menn lærer seg at følelser er irrasjonelle, og derfor tidlig avviser følelser og emosjoner. Den engelske mannsforskeren Vic Seidler skriver skriver i sin bok Man enough? at det menn lærer seg å verdsette, er karriere og prestasjoner som tilhører arbeidslivet. Og fordi de er redde for at andre skal finne ut hvordan de har det, lærer menn seg å bli på vakt og skjule hva de føler (Seidler 1997, 50). Dette er en beskrivelse som langt på vei bekreftes i min studie, i samværet med andre menn opplever mange at det ikke er rom for å snakke om alvorlige temaer. Det er interessant at flere uoppfordret sier at større åpenhet mellom menn på sikt vil kunne gi dem bedre helse og livskvalitet. Dette kan tolkes dithen at mange menn lider under den manglende mannlige åpenheten. Et nærliggende spørsmål er hvorfor menn frykter nærhet og intimitet med andre menn? Er det redselen for at andre menn skal finne ut hvordan de har det, eller kan det være andre grunner til at de fortsetter som før?

\section{Homofobier og lengsler}

Vic Seidler hevder at menn bruker mye tid og krefter på å bevise sin maskulinitet, og når de ikke tør å vise følelser eller sine feminine sider kan det være et tegn på 
menns homofobi (Seidler 1997). I mitt materiale går det fram at homonegativis$\mathrm{me}^{5}$ er en del av håndballspillernes kommunikasjonsmønster. Nylig har en av spillerne på elitelaget stått fram som homofil, dette har ført til at flere av de andre spillerne har følt seg utilpass når han kommer inn i garderoben. 6 Praten stilner, mange blir forlegne og redde for å si noe galt. Den fleipete omgangsformen brytes, og fleipen og køddingen er så innarbeidet i kommunikasjonen at det stadig er en av spillerne som "tråkker i salaten". En av trenerne forteller at han ofte glemmer seg når han blir ivrig, og da slenger han ut karakteristikker han senere angrer på:

"Jeg har sagt ting, som når du tenker på det etterpå, ble sagt i frustrasjon. Når temperaturen blir litt for høy på banen, så brøler jeg ofte ut noen kommentarer som ikke hadde vært noe problem hvis det var en av de andre gutta, men når det er han, så var det kanskje ikke så lurt sagt.”

Noen opplever det som litt urettferdig at de skal legge om stilen, og som en sier: "Det er han som er homofil, ikke sant, og fleipingen er jo en del av miljøet her." Underforstått så mener de at det er den andre som må tilpasse seg den (heteroseksuelle) omgangsformen som gjelder på laget. Når de er ute og reiser med laget skjer noe av det samme, og spillerne påpeker at det er han - den homofile - som er bærer av annerledesheten.

I dusjen og garderoben er spillerne nakne sammen, det er en helt spesiell arena i forhold til seksualitet og kjønn på grunn av kroppsnærheten, mener den norske idrettsforskeren Heidi Eng (2002). Dette kan føre til at toleranseterskelen for en åpen homofil blir ekstra lav. Spørsmålet spillerne stiller seg, er om de kan fortsette å fleipe når de er sammen. "Det spørs jo hvor mye han tåler av fleiping og sånt”, sukker en mens han prøver å forklare meg hva som står på spill:
"Det er jo en del av guttekulturen det å surre med visse sånne grupper da, både dame- og innvandrervitser ... og homsehistoriene er jo også en del av den samme kulturen.”

Likevel er det få som åpent sier at de reagerer negativt på homser, men mange er usikre og ambivalente, kanskje mest fordi det blir et forstyrrende element når de er sammen. Mens noen trekker et klart skille mellom lesber og homser, og de som gjør det er langt mer positive til lesbiske. Eng mener at når lesbiske i større grad enn homser godtas av de mannlige håndballspillerne, kan det bety at menn som deltar $\mathrm{i}$ idretter som assosieres med mandighet og maskuline verdier opplever innslag av feminine verdier i miljøet som truende for deres forventninger om et miljø som er tilstrekkelig maskulint og mandig (Eng 2002). ${ }^{7}$ At det ikke er så greit å stå fram som åpen homofil i toppidretten er uttalelsene til den norske landslagssjefen i fotball:

"Jeg er redd for at pressen ville laget sirkus og fokusert altfor mye på den ene enkeltpersonen framfor lagets innsats og samhold som helhet. Det er nå engang sånn at det er lettere å framstå som en enhet når alle er 'like'." (Åge Hareide til P4 2004)

\section{AvslutTende Diskusjon OG KONKLUSJON}

I denne artikkelen har jeg presentert noen sentrale funn fra inervjuer med 15 idrettsmenn som er eller har vært spillere på et elitelag. Materialet gir et innblikk i mennenes strev med å tilpasse seg ulike forventninger de møter på idrettsarenaen, i kameratgjengen og i familien. Mange av dilemmaene mennene forsøker å håndtere handler om klubbens krav om å være tilstede på trening og kamper, familiens forventninger om at de skal være mer hjemme og deres egne ønsker om å være en moderne far. Det rettes også fokus på de problemer og di- 
lemmaer som mennene forsøker å håndtere i kraft av disse motsetningene.

Et av de dilemmaene som elitespillerne hele tiden møter, er at de må underkaste seg klubbens regler, de er betalt for å være tilstede på treninger og kamper, men kravet lar seg vanskelig kombinere med å være en tilstedeværende far. Håndballspillernes måten å håndtere de ytre kravene på kan sammenliknes med det den svenske mannsforskeren Thomas Johanson (2000) kaller kompromissmaskulinitet. Det betegner maskulinitet hos en gruppe menn som gjerne vil være hjemme med sine barn og leve $\mathrm{i}$ likestilte relasjoner, samtidig som store deler av den mannlige identiteten er sterkt forankret i arbeidsfæren - eller som her - i idrettsfæren.

Et annet dilemma håndballspillerne møter, er konkurransekravet og elitismen som styrer dem inn i et felt hvor det kreves at de hele tiden presterer og viser at de er både tøffe, harde og smarte for å beholde plassen på laget. Connel $(1995,37)$ hevder at de økonomiske forholdene og den organisatoriske strukturen i idrettsfeltet åpner for å produsere hegemonisk maskulinitet ved blant annet eksklusjon og inklusjon, og ved å opprettholde den tradisjonelle arbeidsdelingen mellom kjønnene. På den ene siden får mennene lov til å leve ut den hegemoniske maskuliniteten gjennom idretten, på den andre siden har dyrkingen av denne maskuliniteten sin pris. Det mennene betaler kommer til uttrykk gjennom smerter og skader i kroppen og en kontinuerlig undertrykking av de mer feminine sidene i seg. Det betyr at mennenes kropp og helse satses $i$ et større spill om penger, ære og prestisje.

\section{Menn i vanens makt}

Kroppsfokuseringen og risikoorienteringen blant eliteidrettsutøvere kan også tolkes som en demonstrasjon av sportens betydning innenfor en type hegemonisk maskulinitet som bygger på fysisk dominans. Den kroppslige dominansen bekreftes både ved at spillere som har den mest aggressive spillestilen får dominere, og gjennom en nedvurdering av kvinnelandslaget.

Eliteidrett av denne typen, kan også tolkes som en ritualisering av det mannlige. $\AA$ beskrive seg selv i termer som å ha et sinnsykt temperament, å være en råtass på banen eller fleipe med homofile, kan da være en måte å leve opp til en bestemt mannlighet og beskytte seg mot eller nedtone de mykere sidene i seg selv. Og når menn undertrykker bestemte følelser via trening eller fleiper dem bort, kan det være som Vic Seidler $(1997,43)$ er inne på, fordi de har en frykt for å ikke være 'man enough'. Det kan også være en av grunnene til at menn lar være å snakke om sine lidelser og heller lider i stillhet.

Nå vil flere av mennene i min studie ha en forandring, de ønsker en mer ærlig kommunikasjon med andre menn og mer tid til familien. Problemet er at de ikke vet hvordan de skal få det til.

En måte å bryte med pliktfølelsen overfor klubben og kameratene, og utvikle den kroppslige beredskapen overfor familien, er at menn tar det de erfarer på alvor og endrer sine vaner. Makten som ligger i de kjønnede kroppsvanene - vanens makt - og tregheten som ligger i kroppen og i kjønnsfeltet, må da erobres. For å få det til må menn begynne å tvile på sine vaner og gå inn $\mathrm{i}$ en mer analytisk prosess. ${ }^{8}$ Denne tvilen kan da koples til en erkjennelsesprosess hvor menn starter med å se kritisk på sin egen tenke- og reaksjonsmåte. Da må man bruke tid på å identifisere de vanene som hindrer at endringer kan skje, og avlære seg de gamle kjønnede vanene og innarbeide nye. For å få dette til trengs det tid, og tid er som vi vet et knapt gode $\mathrm{i}$ vår tid. 


\section{NOTER}

1. Kroppsvane er et begrep jeg har hentet fra Bourdieu, og han kopler kroppsvanene til sitt begrep om habitus: "Habitus er et system av disposisjoner, det vil si tanker, følelser og vaner som den enkelte (eller grupper) tilegner seg gjennom praktisk erfaring i et felt (Bourdieu og Wacquant 1992, 234.)

2. Prosjektet har arbeidstittelen "Maskuline kroppsvaner og helseforståelser - kjønn, kultur tradisjon og forandring" og er et tre-åring forskningsprosjekt finansiert av Norges forskningsråd. Jeg har intervjuet 15 toppidrettsmenn og 14 menn som har hatt hjerteinfarkt. I tillegg har fire mastergradsstudenter vært tilknyttet prosjektet og intervjuet andre grupper av menn om deres kroppsvaner og helseforståelser.

3. Her må det tas i betraktning at det er et selektert utvalg. Det kan være slik at de som er rastløse søker seg til eliteidretten.

4. Fleiping og kødding er typiske norske uttrykk, på engelsk heter det teasing eller joking.

5. I følge idrettsforskeren Heidi Eng er homofobi irrasjonell redsel eller aversjon mot homoseksualitet, mens begrepet homonegativisme også dekker negative holdninger til homoseksualitet som ikke er av direkte irrasjonell art. (Eng 2002, 109).

6. Eng (2002) mener at garderoben er en helt spesiell arena i forhold til seksualitet og kjønn på grunn av kroppsnærheten, og at de aktive er nakne sammen i garderoben, dusjen osv. . Dette kan føre til at toleranseterskelen for en åpen homofil blir ekstra lav.

7. Dette gjelder for både menn og kvinner, men det er mennene som er i fokus i denne artikkelen. En mer teoretisk beskrivelse av endring av kroppsvaner - og som gjelder kvinner - se Lilleaas og Fehr 2001.

\section{REFERANSER}

- Bourdieu, P. and Wacquant, L.J.D. (1992): An Invitation to Reflexive Sociology. University of Chicago Press, Polity Press, Illinois.

. Conell, R.W. (1995): Masculinities. Polity Press, Oxford.

- Damasio, A. (2002): Folelsen av hva som skjer.

Pax Forlag A/S, Oslo

- Ekenstam, C. (1998): "Kroppen, viljan \& skräcken för att falla” , I: C. Ekenstam, J. Frykman, T. Johansson, J. Kuosomanen, J. Ljunggren and A. Nilsson (red) Rädd att falla. Gidlunds Förlag. - Eng, H.(2003): Sporting Sex/uality: Doing Sex and Sexuality in a Norwegian Sport Context.
Phd-thesis, Oslo Norwegian University of Sport and Physical Education.

- Engelsrud, G. og Lilleaas, U. B. (1999): Par i bevegelse - opplevelse av arbeids-og kroppsvaner. Arbeidsnotat nr. 3. Senter for kvinneforskning. Universitetet i Oslo.

. Freund, P. (1990): “The expressive body: A common ground for the sociology of emotions and health and illness", I: Sociology of Health \& Illness ( $\mathrm{p}$ 453-477)Vol. 12 No. 4.

. Gordon, D.F. (1995): “Testicular Cancer and Masculinity", I: D. Sabo \& F. Gordon (red), Men s health and illness (pp. 246-265)). Sage, Thousand Oaks, CA.

· Hareide, Å. (224): Intervju i kanal P4 1.juli 2004.

- Helgeson, V, S. (1995): "Masculinity, men s roles, and coronary heart disease", I: D. Sabo \& F. Gordon (red), Men shealth and illness (pp. 68-

104). Sage, Thousand Oaks, CA.

- Johansson, T. (1998): "Muskler, svett och maskulinitet”, I: C. Ekenstam, J. Frykman, T. Johansson, J. Kuosomanen, J. Ljunggren and A. Nilsson (red) Rädd att falla. Gidlunds Förlag.

· Johansson, T.(2000): "Makten, härligheten och kärleken”, I: Socialvetenskapelig tidsskrift 1-2.

- Lilleaas, U.B.(2003): Fra en kropp i ustand til

kroppen $i$ det moderne. Dr. polit. avhandling Rapport 2, Universitetet i Oslo.

- Lilleaas, U.B. Widerberg, K. (2001): Trotthetens tid . Pax Forlag A/S, Oslo:

- Lilleaas, U.B. og Fehr von der, D. (2001):

"Kroppslig beredskap og kroppens kompetanse", I: K. Malterud(red): Kvinners ubestemte helseplager. Pax Forlag A/S, Oslo.

- Messner, M. (1990): "When bodies are weapons: Masculinity and violence in sport", International Review for the Sociology of Sport, 25(3), 203-218. - Seidler, Victor, J. (1997): Man enough?: Embodying Masculinities. Sage, London.

- Sjørup Simonsen, Simon (2003): “Mænds sygdomsbillede - distancering: autonomi eller isolation?", Paper presentert på det første symposium om "Mends sundhed og sygdomme" i Danmark: Rikshospitalet i København.

- White, P., Young,K.\& McTeer, W.G. (1995): "Sport, Masculinity and the Injured Body",In (red) Sabo, Fredrick \& Gordon: Men s Health and Illness: Gender, Power and the Body. s. 158-182.

- Young, K.(1993): "Violence, risk, and liability in male sport culture", Sociology of Sport Journal, 10, 373-396. 


\section{SUMMARY}

This exploratory study investigates how men understand and talk about their body, bodily habits and feelings. The study is based upon qualitative interviews with 15 sportsmen all of whom are handball players. One half of the players play elite sports, and the other group are old boys. The players are very definite about what characterizes a male body; they prefer a slim and well-trained body with strong muscles. Training has become a necessity for many of the sportsmen, and they use physical activity as a way of handling difficult feelings. When they are together, teasing and joking are usually used to handle embarrassing feelings, and they talk more easily with women than men about their problems. Data are discussed in relation to what some researchers describe as men's fear of not being man enough and the theory of habitus.

Ulla-Britt Lilleaas

Institutt for sosiologi og samfunnsgeografi Universitetet i Oslo 